\title{
Kikaigashima is Not So Far Away After All: Japan's Southwestern Borderland
}

\author{
Murai Shōsuke
}

Translated by Kristopher ReEves

\section{Shunkan dies in an otherworldly island}

It was in the year Angen 安元 3 (1177) when Taira no Kiyomori 平清盛 (11181181) was informed of a plot, led by none other than Retired Emperor Go-Shirakawa 後白河 (1127-1192, r. 1155-1158), to overthrow the Taira clan. Among those involved, three men in particular were signaled out as the main ringleaders: a high-ranking Buddhist bishop and custodian of Hosshōji Temple 法勝寺 (located on the eastern periphery of the Heian capital) by the name of Shunkan 俊寞 (n.d.); one of Go-Shirakawa's trusted generals by the name of Taira no Yasuyori 平康頼 (c.1146-1220); a young greenhorn by the name of Fujiwara no Naritsune 藤原成経 (c.1156-1202), who also waited upon Go-Shirakawa. All three of these men were exiled to Kikaigashima 鬼界ヶ島, literally Ogres' Isle, an infamous place located over the raging main, somewhere far, far from the capital. It was rumored that ships seldom made it safely to this lonely island, buffeted as it was on all sides by a merciless sea. Only one year after their exile, Yasuyori and Naritsune received an imperial pardon. Shunkan, however, received no such pardon. Condemned to spend the rest of his days a solitary exile on Ogres' Isle, Shunkan watched in horror as the ship carrying his fellow exiles pulled out towards the offing. He cried out, begging to be transported, if not back to the capital, then at least as far as the island of Kyushu. He begged in vain; the crashing waves drowned out his cries. The ship sailed farther and farther out to sea. Shunkan frantically drummed and stomped his feet, all the while weeping bitter tears, until, at last, the ship could be seen no more, having passed over the white waves beyond. ${ }^{1}$

A legend regarding the after events of this tragic episode states that a monk and disciple of Shunkan's known as Ariō 有王 (n.d.), residing in the capital,

\footnotetext{
${ }^{1}$ Heike monogatari 平家物語, chapter 3, section 2: “The Foot-Drumming," 100. All section titles, page references, and quotations from Heike monogatari are those found in Helen McCullough's full-length English translation, The Tale of Heike (Stanford: Stanford University Press, 1988).
} 
ventured forth over the sea in order to seek out his master on Ogres' Isle. Once reunited, Ariō handed to Shunkan a letter written by the latter's daughter. Not long after reading this letter, Shunkan gave up the ghost, leaving this disciple to carry out his last rites. It is said of Shunkan, in highly conventional language, that "he ceased to consume even his former meager fare, chanted the name of Amida Buddha constantly, and prayed for correct thoughts in his final hour. On the twenty-third day after Ariō's arrival, he died in his rude shelter at the age of thirty-seven." 2 As for Ariō, we are told that he, like a loyal and loving disciple, "climbed mount Kōya with Bishop Shunkan's remains [hung] around his neck, laid the bones to rest in the Inner Cloister, took the tonsure at Rengedani, and wandered as an ascetic over the Seven Circuits, praying for his master's enlightenment in the afterlife."

How do such literary accounts, preserved as they are in the Heike monogatari 平 家物語 (Tale of the Heike), hold up to historical scrutiny? It has already been mentioned that, according to this work, Ogres' Isle was not easily reached by ship. We are further informed that "the few inhabitants [of the island] are unlike people in this country [that is, in the capital]. They are as black as oxen and inordinately hairy, and they cannot understand what others say to them. The men do not wear caps nor do the women let their hair hang free."4 According to this source, to be sure, there are people living on Ogres' Isle. However, they cannot be compared to those living in the capital at Kyoto. With their black complexion and hairy bodies, these savages speak in a tongue that is wholly incomprehensible to any who might chance to set foot on the island. Moreover, the men here walk about without donning the customary cap of a dainty city gentleman. Their women, likewise, do not let their hair hang down in neatly tied locks, as do the primp and proper belles of Kyoto.

It must be understood, first and foremost, that, according to Japanese people living in the medieval period, those dwelling outside of a clearly defined, preconceived boundary were considered synonymous with ogres or savage brutes (oni 鬼). In the common imagination, both then and now, ogres are depicted as having horns protruding from their foreheads, and as belching mist from their mouths. They are, in short, the antipode of civilized human beings. All the same, these inhabitants of Ogres' Isle, despite the fact that they were certainly different than their city-dwelling counterparts, could not properly be called ogres, at least not in any literal sense. Consequently, the inhabitants of this island were endowed, through the literary imagination, with a twofold nature, one that was simultaneously part ogre and part human. Ogres' Isle, so far as the medieval Japanese mind was concerned, represented a liminal zone, one that lay between the moreor-less clearly bounded civilized world, on the one hand, and an amorphous,

\footnotetext{
${ }^{2}$ Heike monogatari, chapter 3, section 9: “The Bishop's Death," 114.

${ }^{3}$ Heike monogatari, ibid, 114-115.

${ }^{4}$ Heike monogatari, chapter 2, section 10: "The Death of the Major Counselor," 82.
} 
largely unknown otherworldly region, on the other; this island was at once within and without the boundaries of normal human habitation.

The name Kikaigashima_-Ogres' Isle_-appears three more times in the Tale of the Heike. We are told, in one such instance, that, upon the death of the mythological Emperor Chūai 仲哀天皇 (n.d.), “'his consort, Empress Jingū 神功皇后, succeeded to the throne, and attacked and subdued Kikai[gashima], Koguryō, and the Khitans as a female ruler." 5 Note that here Kikaigashima is placed alongside the Korean kingdom of Koguryō and the northeast Asian kingdom of the Mongolian Khitans. Elsewhere, in an impassioned letter written by the Taira clan, who had erstwhile been defeated and expelled from the capital, we read of their adamant desire to be invited back to the capital, "otherwise we shall doubtless end up going to Kikaigashima, Korea, India, or China!"' Generally speaking, Korea, India, and China were, at that time, all synonymous with the ends of the earth, and it is revealing to see Kikaigashima at the head of this list. In a similar fashion, Minamoto no Yoshitsune 源義経 (1159-1189), that famous general who played a decisive role in the eventual defeat of the Heike clan, vows to Retired Emperor Go-Shirakawa that "I shall not return to the capital without destroying them [i.e., the rebellious Heike clansmen], even if it means going as far as Kikaigashima, Korea, India, or China." ${ }^{7}$ Here, too, we see Ogres' Isle placed alongside lands then equated with the farthest limits of human habitation.

These examples allow us to reconstruct what must have been the most salient feature of Ogres' Isle as conceived within the medieval Japanese imagination: Kikaigashima marked the outermost boundary of the Japanese kingdom, that place beyond which a court-centered Japan, as such, ceased to exist, and where a host of foreign lands held sway. When Japanese people of the medieval period heard the name Kikai, that is, Ogres' Land, it is very likely they imagined just such a place. Making this the destination of Shunkan's exile would have engendered the aforementioned episode with an exceptionally tragic tone.

\section{Merchant ships loaded with sulfur}

The episode of Shunkan's exile has more to tell. The following brief account is indispensable for a proper historical understanding of Ogres' Isle:

Meanwhile, the Kikaigashima [that is, Ogres' Isle] exiles survived like dewdrops on the tips of grasses. Although life was not to be prized under such circumstances, there were regular shipments of food and clothing to the island from Kasenoshō, a Hizen property belonging to Lesser Captain Naritsune's fatherin-law, Norimori, and thus Bishop Shunkan and Yasuyori were able to stay alive. $^{8}$

\footnotetext{
${ }^{5}$ Heike monogatari, chapter 5, section 1: "The Transfer of the Capital," 166.

${ }^{6}$ Heike monogatari, chapter 10, section 4: "The Reply," 333.

${ }^{7}$ Heike monogatari, chapter 11, section 1: "Reverse Oars," 358.

${ }^{8}$ Heike monogatari, chapter 2, section 15: "Yasuyori’s Prayer," 89.
} 
This passage tells us that Naritsune, the youngest of the three exiles, was fortunate to have as his father-in-law the wealthy Taira no Norimori 平教盛 (11281185), who, as it turns out, owned a private estate in Hizen. It was in virtue of provisions sent over from this estate to Ogres' Isle that the three exiles were able to sustain their lives. The Kasenoshō 鹿瀬荘, or Kase Estate, was located in the southwestern region of modern-day Saga City, nestled in the delta of Ariake Sea, thereby placing this estate along the sea route towards Ogres' Isle. Seen in this light, the island no longer looks like the hopelessly distant, desolate land it was made out to be in the previous section. We are beginning to see a different, less dramatic side of the story. Furthermore, it is possible, if one only looks, to descry these same merchant ships in the tale of Shunkan. When Ariō, Shunkan's loyal disciple, sets out towards Ogres' Isle, we are presented with the following scene:

He reached Satsuma Bay after a long, arduous sea voyage. At the Satsuma port of embarkation for Kikaigashima, he was stripped of his robes by people who called him a suspicious character, but the incident did not make him regret his initial decision. (The daughter's letter was hidden in his top-hair.) He reached the island aboard a merchant vessel. ${ }^{\text {? }}$

Then, when Ariō at last makes the journey back to Kyushu, he "picked up the white bones [of the cremated body of Shunkan], put them in a bag, hung it around his neck, and returned to the Nine Provinces [Kyushu] on a trading ship." 10 From these fragmentary records, it becomes obvious that Ogres' Isle, far from being an island beyond the reach of man, was frequented by merchant ships, and that it was, in fact, one of many convenient ports of call along a longer sea route.

Why, we must ask, did merchant ships see fit to drop anchor at Ogres' Isle? In the same section in which we read of Ariō's embarkation from Satsuma, we also hear Shunkan reveal to his disciple how he has managed to stay alive: "There is nothing to eat on this island. While I still had the strength, I used to go to the mountains and dig sulfur, which I gave to Nine Province [Kyushu] traders in exchange for food, but I am too weak to keep it up now." "There we have it: Shunkan procured food by digging up sulfur and trading it with merchants hailing from Kyushu. Even if we are not prepared to see in this narrative an absolutely accurate reflection of historical fact, we ought to be willing to accept the likelihood that many inhabitants of Kikaigashima did in fact make a living selling sulfur, a local product, to merchants sailing in from Kyushu. During the Muromachi period (1336-1603), the sulfur gathered on Iōjima 硫黄島, literally, Sulfur Island-one of several small outlying islands currently under the jurisdiction of Kagoshima Prefecture-was sold in great quantities, along with sulfur

\footnotetext{
${ }^{9}$ Heike monogatari, chapter 3, section 8: "Ariō," 110.

${ }^{10}$ Heike monogatari, chapter 3, section 9: “The Bishop’s Death," 114.

${ }^{11}$ Heike monogatari, chapter 3, section 8: "Ariō," 111-112.
} 
gathered from volcanoes in various Kyushu estates owned by the Ōtomo family and from Iōtorishima 硫黄鳥島, an island off of northern Okinawa, to eager Ming (Chinese) merchants. The Bakufu even went so far as to send to the Shimazu family estates on Kagoshima a specially appointed official whose duty it was to oversee the sulfur trade.

\section{A fifteenth-century map of Kyushu}

We now see that Kikaigashima-Ogres' Isle_contrary to what the medieval imagination would have us believe, was not a desolate haunt of ogres, but a port of call for merchant vessels travelling to and from the Japanese archipelago. In a collection of maps entitled Haedongjeguggi 海東諸国紀 (J: Kaitō shokokuki, Record of the Eastern Lands), compiled in 1471 by Shin Suk-ju 申叔舟 (14171475), a Korean prime minister and foreign ambassador, we find one map of particular interest entitled Nibonkoku Saikaidō Kyūshū no zu 日本国西海道九州之 図 ("A Map of Kyushu, on the Western Seaboard of Japan," hereafter abbreviated as "Map of Kyushu," see Figure 1 ). A brief note about how this Korean prime minister came to have such a detailed knowledge of the western coast of Kyushu is in order. Earlier, in 1453, a Japanese merchant by the name of Dōan 道安 (n.d.) hailing from Hakata, Fukuoka, made the long sea voyage to Korea. Upon visiting the capital of Seoul, he presented the Korean government with a number of maps, adding to these his own detailed oral account of related matters. Based on these, the Korean government was then able to publish several maps of Japan and the Ryukyu Islands. On the "Map of Kyushu," we see, along the southernmost coast of Kyushu, a cartouche labelled Yamagawaura 山河浦, literally, bay of mountain rivers. Below and to the left of this is another cartouche labelled Iojjima. Directly below this again is a description of the island's sulfur production:

This island produces sulfur, which the Japanese are accustomed to gathering. All of the yellow islands [in this area] produce sulfur. When the sun shines bright upon this island, smoke can be seen floating [up from the volcanoes]. This island is eighteen leagues ( $r i$ 里) from Bō Promontory 房御崎 [located in Satsuma, modern day Kagoshima], and one-hundred thirty-eight leagues from Kamimatsu 上松 [located in Hizen, modern day Saga].

There are two facts we can learn from this. First, as late as the fifteenth century, Japanese merchants were still travelling to Iojima in order to purchase quantities of sulfur. Second, there existed a sea route that allowed these same merchant ships to sail back from Iojima, northward along the western coast of Kyushu, all the way up to Kamimatsura 上松浦 in modern-day Saga, which latter port was but a short distance from the Korean peninsula. The white lines traced on the map represent this and other commonly navigated sea routes.

Let us take a closer look at the sea route traced out along the western coast of Kyushu, paying special attention to a number of prominent geographical features 


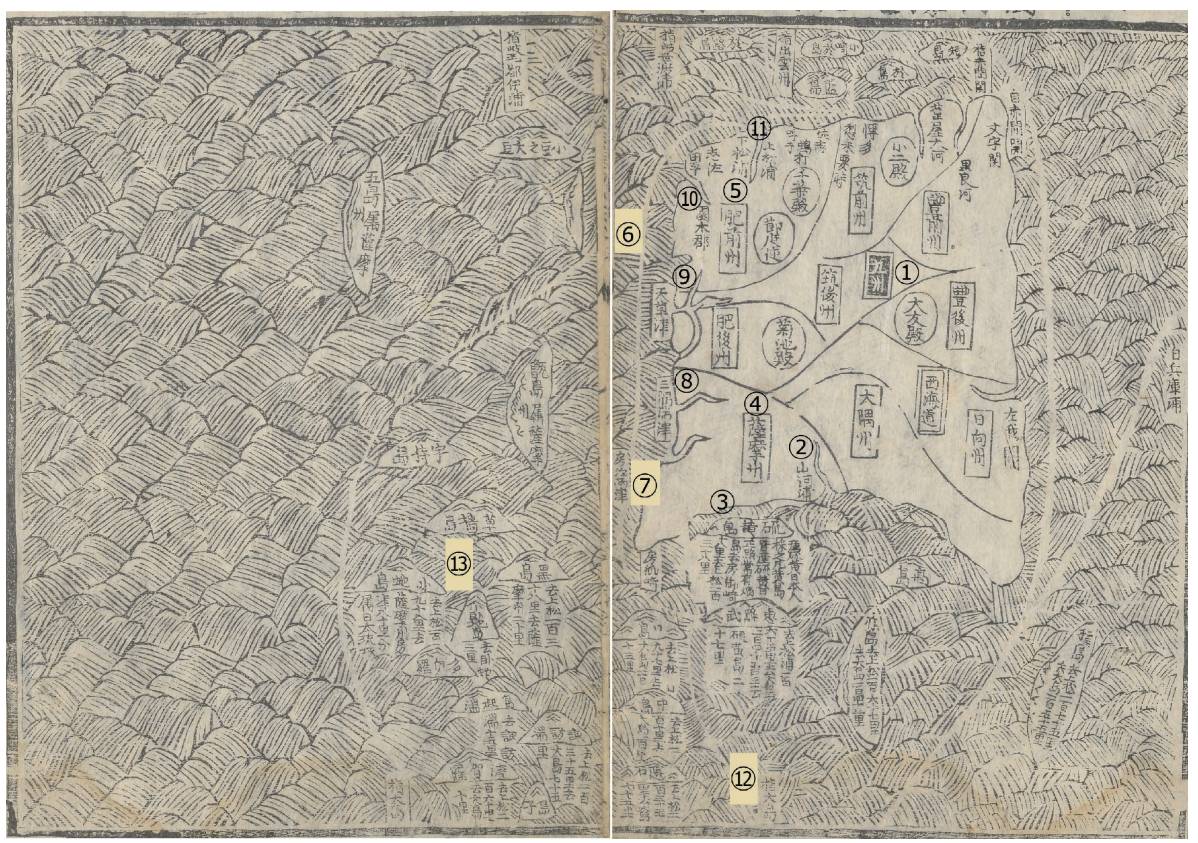

Figure 1. "Map of Kyushu" (detail) from Haedong jeguggi in the Collection from Historiographical Institute The University of Tokyo.

(1) Kyushu (2) Yamagawaura (3) Iōjima (4) Satsuma (Kagoshima)

(5) Hizen (Nagasaki) (6) Sea route (7) The twin harbors od Bō and Tomari

(8) Misumi Port (tentative reading) (9) Amakusa Port

(11) Sonoki County (11) Shimomatsura and Kamimatsura

(12) Cartouche reading "towards Ōshima (the large island)" (13) Gaja Island

https://clioimg.hi.u-tokyo.ac.jp/viewer/view/idata/000/ 000ki 23/2/00000017?m= limit\&n=20

https://clioimg.hi.u-tokyo.ac.jp/viewer/view/idata/000/000ki 23/2/00000018? m= all\& $n=20$

and place names. First, travelling up from the southwestern tip of Satsuma, we come across a cartouche labelled “the twin harbors of Bō and Tomari” 房泊両 津, which corresponds to two areas-Bō 坊 and Tomari 泊—in modern-day Bōnotsuchō 坊津町, Minami-Satsuma (South Satsuma) City, Kagoshima. The two rivers seen flowing westward from the heart of Satsuma are surely the Sendai River 川内川, to the north, and the Manose River 万之瀬川, to the south. A ten-kilometer journey up from the mouth of the Sendai River will bring one to the region known as Sendai, from whence the river gets its name, and where the provincial government office (kokufu 国府) was once located. A five-kilometer journey up the Manose River brings one to an archaeological site known as Mottaimatsu 持躱松, more of which will be said below. Close by Sendai and Mottaimatsu one can still find place names including the term Tōbō 唐坊, “Tang (Chinese) Harbor," which indicates that such a place once served as a settlement for immigrants from Song China. Continuing northward along our sea route, we 
come across another cartouche bearing the following characters 三隅湍津. The correct reading of the third and fourth characters is uncertain. The first two yield the reading Misumi. Hence, let us refer to this place name tentatively as Misumi Port, which corresponds to modern-day Misumi-no-seto 三角ノ瀬戸. There is a slight problem here. Misumi-no-seto is located not in Satsuma but on the tip of the Uto Peninsula 宇土半島, which belongs to the province of Higo (modern-day Kumamoto). It would appear, therefore, that the location of Misumi Port has been mistakenly labelled on the Map of Kyushu. Continuing farther northward, we come across a third cartouche labelled Amakusa Port 天草津, which likely corresponds to modern-day Hondo 本渡, in Shimojima 下島, one of the islands within the Amakusa chain that stretches from western Kyushu to Kagoshima. Passing farther northward, and coming along the coast of Hizen, we then come to a river running northeast into the land. Here we see a fourth cartouche labelled Sonoki County 園木郡, which corresponds to a region, officially written as 彼杵郡, located in modern-day Nagasaki. The body of water facing this county is most certainly Ōmura Bay 大村湾. If we continue northward and round the northwestern bight, we come to a another river, one which is sandwiched between two cartouches, with Shimomatsura 下松浦 to the left, and Kamimatsura 上松浦 to the right. The body of water between these two bays is none other than the modern-day Imari Bay 伊万里湾. Incidentally, there are a number of place names scattered throughout Hizen, such as Tabira 田平, Shisa 志佐, Yobuko 呼子, Kamochi 鴨打, and Sashi 佐志, all of which were taken up as surnames by a close-knit body of warriors, dwelling along the coast, known as the Matsura Confederacy 松浦党.

Let us now return the way we came, following the white line back down along the western coast of Kyushu, until we arrive once more at Iojima. That Iojima was not a final stop but rather a connecting port along a larger sea (trade) route is seen by the fact that the white line continues still farther southward from the southwestern tip of the island. Just at the point where this line disappears at the bottom of the page, we see a cartouche labelled "towards Ōshima (the large island)” 指大島. A look at the Map of the Land of Ryukyu, which continues where our Map of Kyushu ends, and which is likewise contained in Haedong jeguggi, reveals that this large island was considered Ryukyuan territory. Close by this island can be seen two cartouches, one labelled "towards Akama Port and Hyōgo Bay” 指赤間関 ·兵庫浦, the other labelled “towards Erabu” 指恵羅武. Akama Port corresponds to modern-day Shimo-no-seki 下関, while Hyōgo Bay is synonymous with modern-day Kobe. Erabu corresponds to modern-day Kuchi-no-erabu Island 口永良部島, nestled close by Yaku Island 屋久島, presently administered by Kagoshima Prefecture. The white line that continues southward from this large island at last terminates at Naha 那覇, in what is modern-day Okinawa. It must be understood, moreover, that the trade route did not end in the Ryukyu islands. Instead, these islands served as yet another stop along the way towards China, a magnificently far-reaching route which extended all the 
way into Southeastern Asia. In this way, the sea route that passed by Ogres' IsleKikaigashima - was one that allowed enterprising merchants to venture farther and farther out across the sea. Ogres' Isle, therefore, aside from marking the periphery of the (imagined) Japanese civilized world, could also serve as a starting point for distant sea journeys.

\section{Porcelain trade and the proliferation of harbors during the medieval period}

Historians specializing in medieval Japan have recently produced a fair amount of research regarding the history of ports. As a result, not only the history of such famous ports as Hakata Port (Fukuoka), Hyōgo Port (Hyogo), and Sakai Port (Osaka) have been elucidated, but a number of anonymous ports have also received their share of coverage. More than anything else, this enthusiasm has been fueled by the ongoing efforts of archaeological investigation. The number of medieval ports currently being unearthed and investigated by researchers continues to rise at a rapid rate. Ports alone are not the only subject of interest. Archaeologists working at these sites continue to unearth quantities of porcelain goods: artefacts that promise to give us concrete insights into the movement of merchants and transportation of merchandise across trade routes-especially sea routes - throughout the medieval period. Sites of medieval ports found along the coast of Kyushu contain exceptionally large amounts of porcelain trade goods. The sheer number and variety of porcelain goods unearthed from the site of Hakata Port has come to serve as a standard ruler against which the relative age and character of other sites might be measured. While not so numerous as findings in Hakata Port, the composition of porcelain merchandise unearthed from sites along the sea route traced out on our Map of Kyushu reveals unmistakable similarities to products at the Hakata site. That is to say, the white lines on our map mark out what might be referred to as the Porcelain Road, one that linked port to port, and island to island.

In the bottom of the sea just off the west coast of an area known as Kurakizaki 倉木崎, nearby the village of Uken 宇検村, in Amami Ōshima 奄美大島—one of the Ryukyuan islands currently administered by Kagoshima, and located southwest of Kyushu - archaeologists have unearthed what appears to be a cache of porcelain trade goods once stored onboard a merchant ship. The remains of this purported ship, however, have yet to be found. Place names containing the word gusuku, an Okinawan word referring to fortifications, can be found in the village of Uken, a fact that speaks to early trade between the people of Amami Ōshima and those dwelling on the more southern islands of Okinawa.

The archaeological site at Mottaimatsu, located in what was until 2005 the town of Kinpōchō 金峰町, Minami-Satsuma City, Kagoshima, has been mentioned briefly above. Considering the hundreds of porcelain objects unearthed from this site, it is believed that Mottaimatsu, situated as it is on the eastern bank of the aforementioned Manose River, was once a port of discharge, that is, a 
place where merchants could unload their merchandise for trade on land. In fact, the mottai in Mottaimatsu is a dialectical term for pots or earthenware in general. Near the more hilly residential area that faces the main road (running northsouth along the coast of the island), at a point close to where the road crosses the Manose River, one can find a number of archaeological sites, such as that of Kannonji Temple 観音寺, and another, known as the Kosono Site 小薗遺跡, thought to be the remains of a mansion that once belonged to a local estate proprietor. Until very recently, the port at Bōnotsu, located in modern-day Bōnotsuchō, as already mentioned, has received almost exclusive attention as the main trade port of its time. Now, however, in light of more recent archaeological findings, researchers are turning their attention to the lower course of the Manose River, where, it is thought, a favorable lagoon once existed, an ideal resting place for seafaring merchants.

There is an archaeological site, known as the Shiraigawa Site 白井川遺跡, located in modern-day Higashi-sonogichō 東彼杵町, eastern Nagasaki, close by the spot where the Sonoki River 彼杵川 flows into the aforementioned Ōmura Bay. Both the geographical location (at the mouth of a river) and composition of goods unearthed at this site bear a remarkable resemblance to the Mottaimatsu Site. To the west of the Shiraigawa Site, there is what appears to be the remains of a temple_known to researchers as the Oka Site 岡遺跡—by the foot of a range of nearby mountains. The Sonoki River, like the Manose River, was once the site of a lagoon. This area, furthermore, once formed the heart of the Sonoki Estate, owned by Tōfukuji Temple 東福寺, and overseen by its local proprietors, the Sonoki family. Considering the Sonoki Estate eventually grew to embrace the entire county, or, put the other way around, that the entire county was effectively transformed into a private estate, it follows that the cartouche on the Map of Kyushu labelled Sonoki County likely refers to Sonoki Estate.

The Rōkaida Site 楼楷田遺跡, located in Matsuura City 松浦, Nagasaki, has also provided a number of porcelain items similar to those unearthed at the above two sites. On a certain plateau, archaeologists have unearthed the remains of a stone-paved road more than one-hundred meters in length, which, researchers surmise, was once used by people making their way from the port to a yet undiscovered temple. It is thought that this was the headquarters of the Shisa-Shirahama clan 志佐白浜氏, who belonged to the aforementioned Matsura Confederate of martial houses, and that this region was part of the area labelled Shisa on the Map of Kyushu.

\section{Japan's southwestern borderland and the twelve Kikai Islands}

In the fourteenth-century Nagato Manuscript 長門本 of the Tale of Heike, we are told, in relation to Kikaigashima that it was, in fact, not one island but a chain of twelve islands, five of which-referred to as the "five islands about the 
mouth" (kuchi gotō 口五島), that is, the five nearer islands-were under the control of the Japanese court, and seven of which-the "seven islands in the interior" (oku shichito o the court. Scholars agree that Takeshima 竹島, Kuroshima 黑島, as well as the aforementioned Iojjima, were among the five islands that belonged to the court, and that the seven extraterritorial islands refer to the modern-day Tokara Archipelago 吐噶喇列島, currently administered by Kagoshima. So long as we accepting this last conclusion, it follows that the border of the medieval Japanese empire ran through the Tokara Strait. Now, there was a warrior by the name of Chikama Tokiie 千贓時家 (n.d.), trusted vassal and local magistrate for the head (tokusō 得宗) of the Hōjō 北条 clan-which clan was itself the administrative head in the Kamakura shogunate-whose power base was located in Kawanabe County 川辺郡, Satsuma. In the year Kagen 嘉元 4 (1306), just around the time the Nagato Manuscript was completed, Tokiie wrote up a document stating which of his many estates were to be managed by which of his five children: To his eldest son, Sadayasu 貞泰, he entrusted estates on the five islands (kuchi gotô) just mentioned, along with those on Wasa Island わさ島, Kikai (Ogres') Island 喜界島, and Ōshima 大島; to his second son, Tsuneie 経家, he entrusted an estate on the already mentioned Erabu Island; to his third son, Kumayashamaru 熊夜叉丸, he entrusted estates on "the seven islands" (shichito); to his daughter, Himekuma 姫熊, he entrusted an estate on Toku Island 徳之島; to his other daughter, Iyakuma 弥熊, he entrusted an estate located in Shimogōri 下郡, on Yaku Island 屋久島. Here we see not only the seven islands-Tokara Archipelago-but also a number of the Amami Islands, such as Ōshima, Kikai Island, and Toku Island, all of which, according to the Nagato Manuscript, were outside the domain of the Japanese court. ${ }^{12}$

It is plain to see that the imagined boundaries of medieval Japan were not set in stone. The court, at least as represented in the Nagato Manuscript, imagined the border to be somewhere around the Tokara Strait, while those warriors, like Tokiie, dwelling within the peripheries, imagined a somewhat more expansive empire, one which included the Amami Islands. What the court viewed as territory beyond their control, and consequently, as somehow other or alien, local warriors saw as distant estates capable of producing economic wealth. Considering the distribution of Tokiie's many estates, we may safely conclude that the Chikama clan was engaged in lucrative trade with the inhabitants of the southwestern Ryukyu Islands. The same may be said, by extension, of the Hōjō leaders, Tokiie's mighty patrons. By placing Tokiie in Satsuma as their local representative, these leaders gained a firm foothold on the southwestern extremity of the Japanese archipelago. They did the same in the north of Honshu, as well. By stationing men of the Andō 安藤 clan, another of their trusted vassal families, on the coast of Sotogahama 外ヶ浜, which faces modern-day Mutsu Bay,

${ }^{12}$ This document is preserved in the Nagashima Chikama monjo 長島千箍文書. 
Tsuruga Peninsula, Aomori, the shogunate engaged in trade with the local Emishi 蝦夷 people.

While Kawanabe County was primarily under the control of the Hōjō shogunal administrators, the Shimazu 島津 clan, as provincial constable or military governor (shugo 守護), the family responsible for maintaining order and peace in Satsuma, also had a degree of influence in the area. In the year Karoku 嘉禄 3 (1227), Shimazu Tadahisa 島津忠久 (?-1227) formally invested his heir, Tadayoshi 忠義 (n.d.), with the dual post of local estate steward (jitō 地頭) and provincial constable (shugo) of Satsuma. In the investiture document, Tadahisa explicitly states that Tadayoshi was to exercise control over all of Satsuma, excepting the Isaku Estate 伊作庄, Kawanabe County, and Ibusuki County 指宿郡. ${ }^{13}$ Fujiwara no Yoritsune 藤原頼経 (1218-1256), fourth shogun (1226-1244) of the Kamakura shogunate, who officially approved this inheritance, stated that Tadayoshi was to receive the position of local estate steward (jito) of all the twelve islands (jünitō jutosshiki 十二嶋地頭職) save Kawanabe County. ${ }^{14}$ The position of local estate steward of all the twelve islands was initially created by Minamoto no Yoritomo 源頼朝 (1147-1199), founder of the Kamakura shogunate, after subjugating those rebel forces that had escaped to Kikai Island. Yoritomo saw fit to invest the Shimazu clan with this position, as an adjunct to their preexisting estate in Kawanabe County, Yorigōri 寄郡, Satsuma.

Eventually, in the wake of the Jōkyū Disturbance of 1221, control over Kawanabe County returned to the hands of the Hōjo leaders (tokusô). According to a declaration written up in Kannō 観応 3 (1352) by Ashikaga Tadafuyu 足利直冬 (c.1327-1387/1400), illegitimate child of Takauji, first shogun of the Muromachi shogunate, the Hojjō leaders exercised authority over Kawanabe County in the dual capacity of local estate stewards (jito ) and county or district officials (gunji 郡司). ${ }^{15}$ What the Shimazu clan inherited in relation to the twelve islands was the position of local estate steward. The Hōjō leaders retained for themselves the position of local governor over all the remaining southern islands, as well as the position of county official (gunji) over Kawanabe County. The Chikama clan, in their turn, served as representatives of the local estate stewards (jitō daikan 地頭代官) over the twelve islands, as well as county officials over the whole of Kawabe County. This latter position, in actual fact, extended beyond the twelve islands to include authority over the Amami Islands, as well.

In the year Genkō 元弘 3 (1333), when the Hōjō leadership had crumbled, the twelve islands became the sole property of the Shimazu clan. Ashikaga Yoshiakira 足利義詮 (1330-1367), second shogun of the Muromachi shogunate (1359-1367), who, in Enbun 延文 1 (1356), wrote up a document confirming the estates of

\footnotetext{
${ }^{13}$ This document is preserved in Kamakura ibun 鎌倉遺文, document no. 3621 .

${ }^{14}$ This document is preserved in Kamakura ibun 鎌倉遺文, document no. 3670 .

${ }^{15}$ This document is preserved in Nanbokuchō ibun: Kyüshū ben 南北朝遺文九州編, document no. 3317.
} 
Shimazu Sadahisa 島津貞久 (1269-1363), declared that the Shimazu clan were indeed the rightful local estate stewards of the twelve islands. ${ }^{16}$ In another document, dated Jōji 貞治 2 (1363), in which Sadahisa bequeaths his estates to his son Morohisa 師久 (1325-1376), it is declared that Kawanabe County, under the jurisdiction of the Shimizu clan, consisted of both the twelve islands as well as "five other islands." ${ }^{17}$ While the precise identity of these five islands is uncertain, it is possible that they refer to the Amami Islands.

\section{The border between Ryukyu and Korea}

It is well understood that the sea route running east and west from Japan to China through the East China Sea, along with the large port city of Hakata, served as major features in delineating the western border of medieval Japan. There was, however, a second sea route that likewise played an important role in defining the western border of Japan. This sea route, which extends from south to north, and crosses over the former east-west route at Hirado, a cluster of islands in what is now northern Nagasaki, begins in the Ryukyu islands, and continues northward to Kikaigashima (Ogres' Isle), the western coast of Kyushu, Iki, Tsushima, arriving finally at the Korean peninsula. When looked at from the perspective of this south-north route, the western border of Japan extends to Ryukyu and Korea.

Some places labelled on the Map of Kyushu include a note regarding their distance, in Japanese leagues ( $r i)$, from a given place. The reason why this map, though published in Korea, includes measurements in Japanese and not Korean leagues lies in the fact, as noted above, that the original maps were brought over from Japan by a Hakata merchant by the name of Dōan. The three most commonly mentioned points of reference in regards to distance on this map are, first, Kamimatsura (hereafter abbreviated as Kamimatsu), second, Ōshima (which refers to Amami-ōshima), and, third, Bōnotsu, in Satsuma. For example, the label for Erabu (Kuchinoerabu Island) states that the island may be reached 154 leagues out from Kamimatsu, or 245 leagues out from Ōshima. Gaja Island 小 蛇島, now written 臥蛇島, which belongs to the Tokara Islands, includes a similar note, stating that the island may be reached 198 leagues out from Kamimatsu, or 80 leagues out from Bōnotsu. Note that all three of these reference points are important stops along the south-north sea route, and that, conversely, no mention is made of Hakata port, the most important stop on the east-west sea route.

Recall that Chikama Tokiie, the year Kagen 4 (1306), invested his eldest son with, among others, an estate on Wasa Island, the location of which has continued to allude scholars. Hashimoto Yū 橋本雄 has offered a possible answer, pointing out the fact that the Gaja in Gaja Island is, in Korean, pronounced Wasa 와사; it

\footnotetext{
${ }^{16}$ This document is preserved in Nanbokuchō ibun: Kyūshū hen 南北朝遺文九州編, document no. 3891.

${ }^{17}$ This document is preserved in Nanbokuchō ibun: Kyüshū hen 南北朝遺文九州編, document no. 4467.
} 


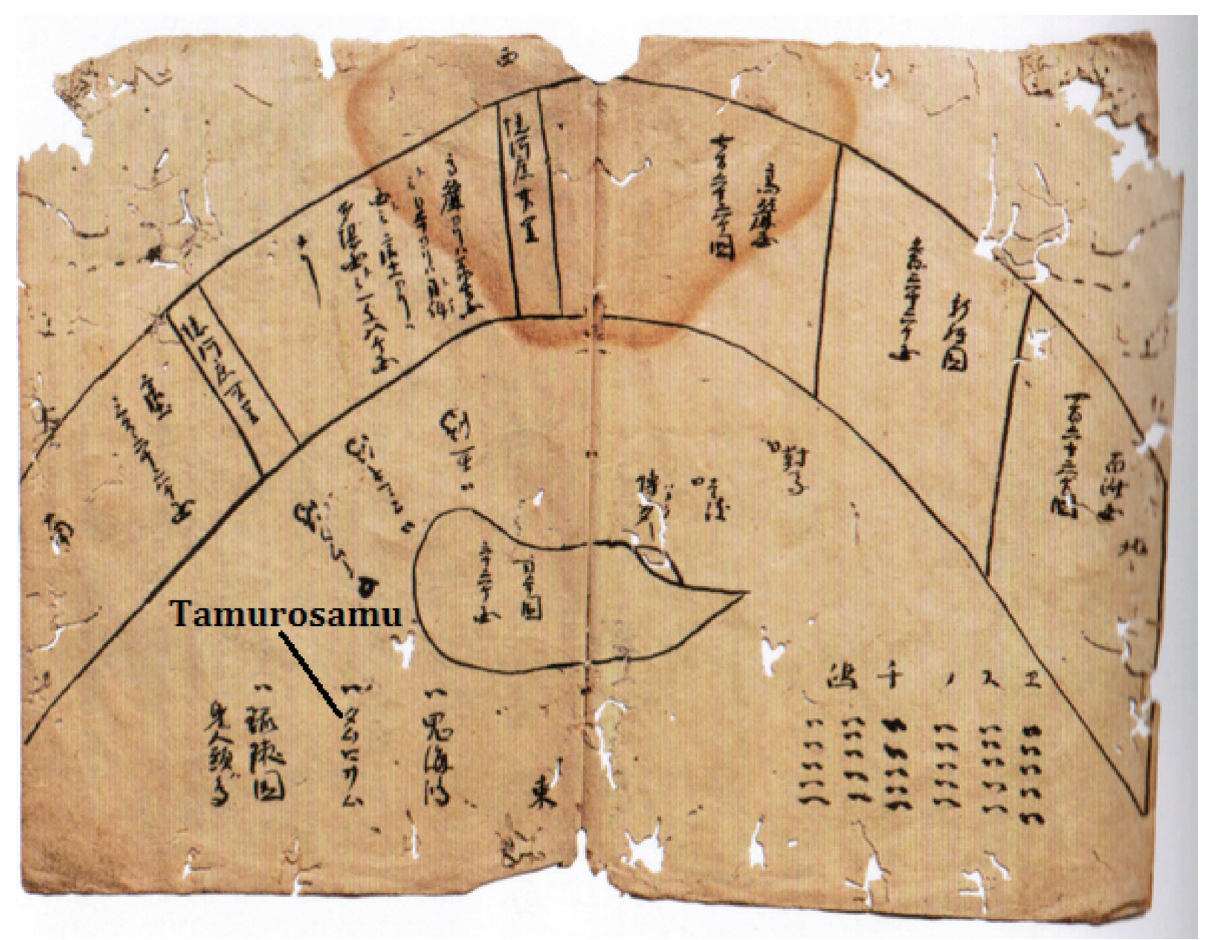

Figure 2. "Myōhonji Map of Japan," showing the location of Tamurosamu, that is, Jeju Island, from Zuroku Nichiren shōnin no sekai 図録日蓮聖人の世界, eds. Nichiren shōnin no sekaiten jikkō iinkai, 日蓮聖人の世界展実行委員会, Ōsaka: Genryūji 原立寺.

is possible that Wasa Island corresponds to Gaja Island. This possibility is enforced by a number of fifteenth-century Korean documents in which Gaja/Wasa Island is given special attention in virtue of the fact that it was seen as traversing the boundary between the Ryukyu Islands and Satsuma. This might also account for the curious practice, on records of inheritance and other estate-related documents, of listing Gaja Island separately from the aforementioned seven islands (shichito), even though the former was generally understood as belonging to the latter. There is a certain map of Japan, stored at Myōhonji Temple (in modern-day Kyonan Town, 鋸南町, Chiba)—known as the "Myōhonji Temple Map of Japan" 妙 本寺蔵日本図 (Figure 2)-which reflects the geographical understanding of Muromachi-period Japan. On this map, Jeju Island 済州島, the largest island of the coast of the Korean Peninsula, and currently administered by South Korea, is written as 耽羅, which, though usually read as Tamura, is here rendered as Tamurosamu タムロサム. Very likely, this final samu is a phonetic approximation of the Korean word seom 섬, that is, island. What these two examples indicate is this: the south-north sea route, passing as it did through Korean waters, served to introduce Japanese navigators to the Korean names of certain islands, named which were recorded, albeit in a somewhat mutilated form, on Japanese maps. 
In the first half of the fifteenth century there was a man by the name of Kim Won-jin 金元珍 (n.d.) who travelled widely across the south-north sea route, engaged in trade, foreign diplomacy, and ship building. Although he was, ethnically speaking, Korean, when left Kyushu and arrived in Korea, he was referred to by the local Koreans as a Japanese man (wajin 倭人). He referred to himself as the messenger of Minamoto no Habuku 源省 (n.d.), a man stationed on Tabira, just across from Hirado, or, at other times, as the messenger of Minamoto no Sadashi 源貞 (n.d.) and Minamoto no Yoshi 源義 (n.d.), both of whom were stationed on Hirado itself. All of these Minamoto men belonged to the Matsura Confederacy. In 1423, Kim engaged in negotiations with Shimazu Hisatoyo 島津久豊 (13751425), eighth head of the Shimazu clan, and local protector (shugo) of Hyūga 日 向, Satsuma, and Ōsumi 大隅, that is, modern-day Miyazaki, western and eastern Kagoshima. Kim petitioned Hisatoyo for the release of Korean prisoners of war that he might transport them back to their native Korea. Some seven years later, in 1430, Kim, as official interpreter or envoy for the Kingdom of Ryukyu, delivered a diplomatic document sent by Liang Hui 梁回 (n.d.), a Fujian-born magistrate then governing in the capacity of grand councilor (changshi 長史) in Ryukyu, to the Korean government. In 1435, Kim requested permission to fell tress for the purpose of procuring ship building material. His request was denied. At this time, incidentally, Kim was accompanied by a certain Ryukyuan shipwright by the name of Ōsato 大里, who expressed a desire to become a subject of the Korean kingdom, which desire was granted.

\section{References}

Hashimoto Yū 橋本雄, “Chūsei no Kikaigashima, Nansei shotō, Kanhigashi Shinakai” 中世の喜界島・南西諸島・環東シナ海, in Ikeda Yoshifumi 池田笟 史, ed., Kikaigashima kenkyù sbinpojiumu: kodai, chüsei no kikaigasbima shiryōben 喜 界島研究シンポジウム 古代・中世のキカイガシマ資料編, 2005.

Ikeda Yoshifumi 池田榮史, ed., Kodai chüsei no kyōkai ryöiki: Kikaigashima no sekai 古代中世の境界領域 キカイガシマの世界, Tokyo: Koshi shoin, 2008.

Kreiner, Josef ヨーゼフ・クライナー, Yoshinari Naoki 吉成直樹 and Oguchi Masashi 小口雅史, Kodai makki, Nihon no kyōkai: Gusuku isekigun to Isbie isekigun 古代末期 ・ 日本の境界一城久遺跡群と石江遺跡群, Tokyo: Shinwasha, 2010.

Murai Shōsuke 村井章介, Chüseishi kenkeyū no tabiji: sengo rekishigaku to watashi 中世 史研究の旅路一戦後歴史学と私, Tokyo: Azekura shobō, 2014.

Murai Shōsuke 村井章介, Kyōkai wo matagu bitobito (Nibonshi riburetto 28) 境界をま たぐ人びと〈日本史リブレット28〉, Tokyo: Yamakawa Shuppansha, 2006.

Murai Shōsuke 村井章介, Kyōkaishi no kōsōo (Nihon rekishi watashi no saishin kōgi 12) 境界史の構想〈日本歴史私の最新講義12〉, Tokyo: Keibunsha, 2014.

Yamauchi Shinji 山内晋次, Nissō böeki to “iō no michi” (Nibonshi riburetto 75) 日宋貿 易と「硫黄の道」〈日本史リブレット75〉, Tokyo: Yamakawa Shuppansha, 2009. 